\title{
Identification of the Female-Specific DNA Fragments in Chickens
}

\author{
Hiroshi Kagami and Takeshi Tomita \\ Laboratory of Animal Genetics, Faculty of Agriculture, \\ Nagoya University, Nagoya, Japan, 464
}

\begin{abstract}
It was previously demonstrated that when the genomic DNA of the chicken was digested with restriction enzyme, XhoI, and analyzed by agarose gel electrophoresis with ethidium bromide as a staining agent, a DNA fragment of about $0.7 \mathrm{kbp}$ was detected specifically in the female (KAGAMI and TOMITA, 1990). In the present study, the $\mathrm{W}$ chromosome-specific DNA probe was found to hybridize with the initially detected female specific DNA fragment mentioned above.

Consequently, it was concluded that the initially detected female specific DNA fragment of about $0.7 \mathrm{kbp}$ was homologous to the $\mathrm{W}$ chromosome-specific DNA probe.
\end{abstract}

(Jpn. Poult. Sci., 29 : 156-160, 1992)

Key words : Chickens, Female-specific DNA fragments, W-specific DNA probe

\section{Introduction}

Since the $\mathrm{W}$ chromosome is female specific in chickens, it has been considered that the genes on the $\mathrm{W}$ chromosome play important roles in primary sex determination. Scientific works have been performed to clarify the role of the $\mathrm{W}$ chromosome. Direct cytological evidence for the $\mathrm{W}$ chromosome was presented as an unpaired acrocentric chromosome of the size class of No. 7-8 in female chicken cells ${ }^{1}$. And entire regions of the $\mathrm{W}$ chromosome in methaphase were found to be stained with $\mathrm{C}$-banding $\operatorname{method}^{2)}$.

Recently, the W chromosome-specific DNA fragments were cloned ${ }^{3)}$. However, the meaning of the repetitive DNA units in the $\mathrm{W}$ chromosome is still uncertain. And the knowledge about the $\mathrm{W}$ chromosome at molecular level is scanty as compared with that of the mammalian $\mathrm{Y}$ chromosome ${ }^{4)}$.

In the present study, detection of the female-specific DNA fragments was performed by hybridization of the cloned DNA probe to the genomic DNA of the chicken digested with a restriction enzyme, Xhol.

\section{Materials and Methods}

Blood samples of $1 \mathrm{ml}$ were taken with a heparin-wetted syringe from the wing vein of White Leghorn chickens aged eleven months. High molecular DNA was prepared and digested with Xhol. The DNA was subjected to electrophoresis in 
agarose gel, stained with ethidium bromide and photographed through a conventional UV transilluminator at $254 \mathrm{~nm}^{5,6)}$. The DNA was transferred from the gel to a sheet of nylon membrane (Amersham, Hybond-N +) by capillary method ${ }^{7}$.

One ng of plasmid DNA (pUGD 06000) which contained the W chromosome-specific $0.7 \mathrm{kbp}$ DNA unit was transformed to competent cells (Escherichia coli DH $5 \alpha$ ). The transformed bacteria was incubated overnight at $37^{\circ} \mathrm{C}$ in $3.5 \mathrm{ml}$ of $\mathrm{LB}$ medium containing Ampicilin. Lysis of the bacteria was done by adding $200 \mu l$ of alkaline solution $(0.2 \mathrm{~N} \mathrm{NaOH}$ and $1 \% \mathrm{SDS})$ and the plasmid DNA was harvested. The DNA was double digested with restriction enzymes BamHI and PstI, and the insert of the $0.7 \mathrm{kbp} \mathrm{W}$ chromosome-specific DNA fragments were recovered. The DNA fragments were labelled with horseradish peroxidase (Amersham) and used as W-specific DNA probe.

Pre-hybridization of the membrane was done for 1 hour at $42^{\circ} \mathrm{C}$. Initially labelled DNA probe was added and the hybridization was carried out at $42^{\circ} \mathrm{C}$ overnight. After washing the membrane with primary wash buffer $(0.4 \%$ SDS and $0.1 \times S S C)$ and secondary wash buffer ( $2 \mathrm{xSSC}), 0.0625 \mathrm{ml} / \mathrm{cm}^{2}$-membrane of the detection solution (Amersham) was added and incubated precisely 1 minute at room temperature. Exposure to a sheet of film (Hyperfilm-ECL, Amersham) was carried out for 1 hour.

\section{Results}

When the genomic DNA of the chickens were digested with XhoI and stained with ethidium bromide, the electrophoretic patterns of the DNA were easily distinguished between the male and female. In the female, a DNA fragment was clearly detected as a dense band at about $0.7 \mathrm{kbp}$ (Fig. 1 ; lanes 6,7 and 8 ). In the male the fragment

\section{8}

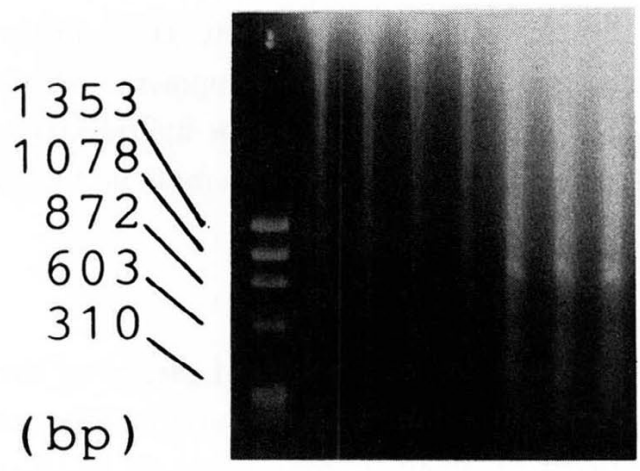

Fig. 1. Digestion of the chicken genomic DNA with XhoI and detection of the female specific DNA fragments. The male genomic DNA is in the lanes 2, 3, 4 and 5. The female genomic DNA is in the lanes 6,7 and 8 . The DNA size marker ( $\phi \times 174-$ HaelII digest) is shown in lane 1. 


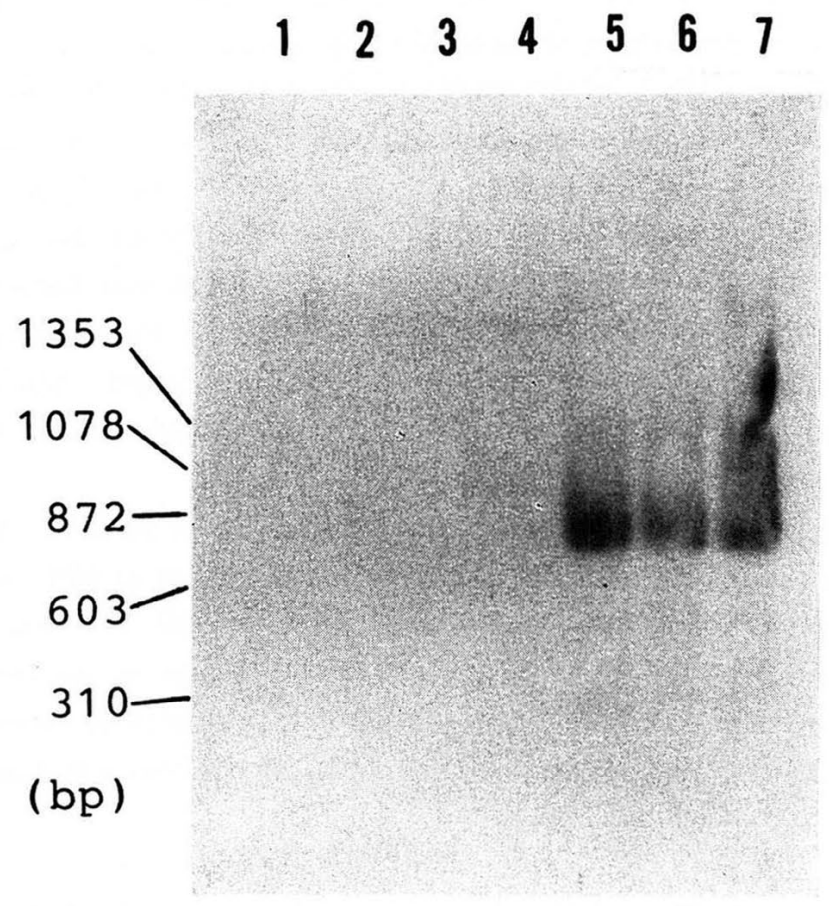

Fig. 2. Hybridization of the $\mathrm{W}$ chromosome-specific DNA probe to the XhoI digested chicken genomic DNA. The male genomic DNA is in the lanes $1,2,3$ and 4 . No hybridization could be detected. The female genomic DNA is in the lanes 5,6 and 7 . Hybrid bands with the probe are detected at about $0.7 \mathrm{kbp}$.

could not be detected (Fig. 1 ; lanes 2, 3, 4 and 5).

Hybridization of the $\mathrm{W}$ chromosome-specific DNA probe to the digested and electrophoretically separated genomic DNA fragments showed a clear difference between male and female. In the female, a major hybridization band was detected at about $0.7 \mathrm{kbp}$ (Fig. 2 ; lanes 5,6 and 7). In the male no hybridization band could be detected (Fig. 2 ; lanes 1,2,3 and 4).

\section{Discussion}

In the previous study, we have reported that digestion of the chicken genomic DNA with restriction enzyme, XhoI, and staining with ethidium bromide led to the detection of a specific DNA fragment at about $0.7 \mathrm{kbp}$ in female (KAGAMI and TomitA, 1990). Hybridization of the W chromosome-specific DNA probe to the digested DNA also showed a major hybrid band at about $0.7 \mathrm{kbp}$ in female. Consequently, it was identified that the initially detected band at about $0.7 \mathrm{kbp}$ correspond to the $\mathrm{W}$ chromosome-specific DNA fragment.

In chickens, entire region of the $\mathrm{W}$ chromosome was stained with $\mathrm{C}$ banding 
method $^{2)}$. Generally, this method is considered to detect constitutive heterochromatin which include satellite or highly repetitive DNA. Thus, it was considered that the detected female specific DNA fragments constitute the heterochromatic region on the W chromosome ${ }^{3,8)}$.

\section{Acknowledgments}

We wish to express our sincere thanks to Professor Dr. Shigeki Mizuno, Laboratory of Biochemistry, Faculty of Agriculture, Tohoku University, for providing us the W chromosome-specific DNA probe of the chicken. Present study was supported by a Grant-in-Aid for JSPS Fellowships for Japanese Junior Scientist (0771).

\section{References}

1) Schmid, W. (1962) DNA replication patterns of heterochromosomes in Gallus domesticus. Cytogenet., $1: 344-352$.

2) Stefos, K. and F.E. Arrighi (1971) The heterochromatic nature of the $W$ chromosome in birds. Exp. Cell Res., $68: 228-231$.

3) Tone, M., Y. Sakaki, T. Hashiguchi and S. Mizuno (1984) Genus specificity and extensive methylation of the $\mathrm{W}$ chromosome-specific repetitive DNA sequences from the domestic fowl, Gallus gallus domesticus. Chromosoma, 89 : 228-237.

4) Koopman, P., J. Gubbay, N. Vivian, P. Goodfellow and R. Love-Badge. (1991) Male development of chromosomally female mice transgenic for Sry. Nature, 351 : 117-121.

5) Kagami, H., H. Nakamura and T. Tomita (1990) Sex Identification in Chickens by Means of the Presence of the W Chromosome-Specific Repetitive DNA Units. Jpn. Poult. Sci., 27 : 379-384.

6) Kagami, H. and T. Tomita (1990) Sexing of Chickens by Detection of the W Chromosome-Specific Highly Repetitive DNA Units. Tokai J. Anim. Prod., 1: 43-47.

(in Japanese with English Summary)

7) Southern, E.M. (1975) Detection of specific sequences among DNA fragments separated by gel electrophoresis. J. Mol. Biol., 98: 503-517.

8) Kodama, H., H. Saitoh, M. Tone, S. Kuhara, Y. Sasaki and S. Mizuno (1987) Nucleotide sequences and unusual electrophoretic behavior of the $\mathrm{W}$ chromosomespecific repeating DNA units of the domestic fowl, Gallus gallus domesticus. Chromosoma, $96: 18-25$. 


\title{
ニワトリにおける雌特異的 DNA 断片の同定
}

\author{
鏡味 裕・富田 武 \\ 名古屋大学農学部家畜育種学教室 名古屋市
}

著者らはすでに, ニワトリのゲノムの DNA を制限 䣼素 XhoI で切断し，アガロースゲル電気泳動法によ り DNA 断片の分離を行ったところ, 雌特異的な約 $0.7 \mathrm{kbp}$ の DNA 断片が検出されることを確認した (Kagami and Tomita, 1990)。この論文では，この DNA 断片をナイロンメンブレンに固定し, 既にクロー ニングされているニワトリの $\mathrm{W}$ 染色体特異的 DNA プ ローブを用いてハイブリダイゼーションを行ったところ，
約 $0.7 \mathrm{kbp}$ において雌特異的にハイブリダイズするこ とを確認した。以上の結果から, 制限酵素 Xhol の切 断により検出された約 $0.7 \mathrm{kbp} の$ DNA 断片は, ク口 ーニングされたニワトリの W 染色体特異的 DNA プ ローブと相同なフラグメントであることが確認された。

（家禽会誌，29：156-160，1992）

キーワード：ニワトリ，雌特異的 DNA 配列, W 染色 体特異的 DNA プローブ 